\title{
Transforming Local Climate Adaptation Organization: Barriers and Progress in 13 Swedish Municipalities
}

\author{
Ann-Catrin Kristianssen ${ }^{1}$ and Mikael Granberg $2,3,4, *$ (D) \\ 1 School of Humanities, Education and Social Sciences, Political Science, Örebro University, \\ SE-701 82 Örebro, Sweden; ann-catrin.kristianssen@oru.se \\ 2 The Centre for Societal Risk Research and political science, Karlstad University, 65188 Karlstad, Sweden \\ 3 The Centre for Natural Hazards and Disaster Science, Uppsala University, SE-752 36 Uppsala, Sweden \\ 4 The Centre for Urban Research, RMIT University, Melbourne, VIC 3001, Australia \\ * Correspondence: mikael.granberg@kau.se
}

Citation: Kristianssen, A.-C.; Granberg, M. Transforming Local Climate Adaptation Organization: Barriers and Progress in 13 Swedish Municipalities. Climate 2021, 9, 52. https://doi.org/10.3390/cli9040052

Academic Editor: Chris Swanston

Received: 25 February 2021

Accepted: 27 March 2021

Published: 30 March 2021

Publisher's Note: MDPI stays neutral with regard to jurisdictional claims in published maps and institutional affiliations.

Copyright: (c) 2021 by the authors. Licensee MDPI, Basel, Switzerland. This article is an open access article distributed under the terms and conditions of the Creative Commons Attribution (CC BY) license (https:// creativecommons.org/licenses/by/ $4.0 /)$.

\begin{abstract}
Local strategies and policies are key in climate adaptation, although research shows significant barriers to progress. Sweden, often seen as progressive in climate change issues, has struggled in adopting a sufficient local climate adaptation organization. This article aimed to describe and analyze the climate adaptation organization in 13 Swedish municipalities from five perspectives: Problem framing, administrative and political agency, administrative and political structures, measures and solutions, and the role of learning. The mapping of these perspectives provides an opportunity to analyze barriers to local climate adaptation. Key policy documents have been studied including climate adaptation plans, crisis management plans, and regulatory documents, as well as documents from private consultants. This study showed that few municipalities have a formal organization for climate adaptation, clear structures, political support, and specific climate adaptation plans. At the same time, many of the municipalities are planning for transformation, due to a push from the county board, a lead agency in climate adaptation. There are also ample networks providing opportunities for learning among municipalities and regions. This study concluded that one key barrier is the lack of focus and prioritization in a majority of the municipalities, leaving the administrators, often planners, in a more activist position. The need for organizational mainstreaming and resources is emphasized.
\end{abstract}

Keywords: climate adaptation; local government; transformative learning; climate adaptation policy; organizational change

\section{Introduction}

The impacts of climate change are disruptive with broad implications for society, managed ecosystems, and the natural world [1-3]. Biodiversity loss, threats to human health, disruptions in food production, shifts in vector-borne diseases, etc. will increase with anthropogenic climate change, and are already visible in many parts of the world. In addition, sea level rise, coastal flooding, extreme heat, and degraded air quality in densely populated cities threatens the lives and wellbeing of millions of people living around the world [4-10]. These comprehensive threats require action at all levels including all spheres of society, and there are already tangible climate change impacts warrants assessing risks, preparing for, and responding to these impacts [11,12]; that is, climate adaptation in terms of social responses to, actual or anticipated, climate change impacts.

The local level is often focused on and considered important in climate adaptation research and policy [13-17]. Furthermore, it is evident that the climate crisis is a threat to urban settlements, while the number of urban dwellers as a result of ongoing urbanization leads to increased vulnerability to climate related events [2,18]. The prognosis for the future is quite bleak as it entails an increased occurrence and severity of weather and climaterelated hazards to urban settlements $[1,2]$. Hence, local strategies and policies are key in 
climate adaptation [19]. At the same time, studies show that despite the growing focus on the role of the local level, there are still major organizational barriers [12,20]. One challenge has been the lack of focus on adaptation in favor of climate change mitigation. Another aspect concerns different views within municipalities on what structures, strategies, and policies are needed to push the progress climate adaptation forward. A third problem is the lack of proper forums for learning.

As the discussion above shows, research on climate adaptation and climate risk reduction emphasize the importance of site-specific, local knowledge and participation [21-24]. In this article, we focused on urban settings and planning and present a study of Swedish municipal climate adaptation. The Swedish welfare state model centers on the municipalities as the central actors responsible for ensuring the welfare of the citizens [25]. In Swedish national climate change policy, municipalities play an important role in the adaptation to climate change (called climate adaptation in this article). This was emphasized in the National Strategy for Climate Adaptation [26].

The Swedish welfare state model is advanced and mature, and one point of departure in this article is that politics and policy in mature welfare states tend to differ fundamentally from politics and policy in less mature welfare state settings [27]. The second, and perhaps more important, point of departure is that Sweden has over decades been considered a pioneer in environmental governance combining nationally high ambitions with strong municipalities [28,29]. However, several studies have indicated difficulties in the municipal efforts, involving everything from how problems are formulated and prioritized and how climate adaptation is organized to issues in the implementation of concrete measures [30-34]. Hence, Sweden provides an interesting context for case studies of climate adaptation and therefore this study can contribute to a broader understanding of climate adaptation, adding knowledge to existing studies of society's handling of climate risk vulnerability, risk reduction, and climate adaptation measures in other geographical, cultural and governance settings.

In this article, the aim is to describe and analyze how 13 municipalities, which are part of a municipal association in the studied region, work with climate adaptation. The studied region is located close to the water (sea and rivers) and has experienced floods and landslides and due to changing climate conditions, these hazards are expected to be more serious in the future. These hazards, and risks connected to them, are central challenges for climate change adaptation in the region.

Overall, we are interested in what the municipal organization for climate adaptation looks like. Is it a matter of incorporating the climate adaptation in existing municipal structures, or is it perceived as requiring innovating new procedures and organizational forms, which often means learning from others? We are interested in understanding how Swedish municipalities, in an area with proximity to the sea and large rivers, are structuring their work and how it is developing.

We focused on three questions:

1. How is climate adaptation regulated, organized, structured, reformed, and implemented in the municipalities?;

2. What is the role of learning in climate adaptation practice?;

3. What barriers can be identified?

The study includes a large enough number of municipalities to provide the basis for an interesting principal discussion regarding how Swedish municipalities work with climate adaptation today, what challenges and problems they face, and how they organize their work.

\section{Theoretical and Analytical Approach}

Effective adaptation not only warrants adaptation to the physical element of a changing climate, but also transformative forms of governance that go beyond adjustments $[12,17,19,35-38]$. Changes to a policy system can lead to different, often unpredictable, outcomes [39] and, furthermore, the policy system is an expression of " ... the dominant, institutionalized policy frames and knowledges" [38]. Hence, the policy or governance system of climate 
adaptation consist of institutionalized arrangements such as organizational settings, rules, knowledge, etc., which are, at the same time, part of a broader social and political context $[12,40]$. At the same time, governance actors mobilize and change the conditions for collective action through their agency [41].

This institutional perspective has implications for the potential pathways for, and understanding of, transformation [38]. Scholars have argued for understanding a transformational change as continuous and change that gradually unblocks stagnation, and this warrants a focus on generating "small wins" rather than rapid, in-depth, and revolutionary change [42]. Small changes, it is argued, can over time develop into large-scale transformative change. This points towards the need for a transformative climate governance (for an extensive discussion and empirical examples see [43]) and this has to include organizational and transformational learning. Climate adaptation has to involve forward-looking learning under uncertain and complex circumstances [44].

Hence, this study focused on the development of organizational procedures (organizational learning and change), and on how learning with regard to climate change impacts happens in public organizations (especially transformational learning). Policy studies and public administration research highlight that public policy and its administration is a complex multi-scalar adaptive system [45]. Hence, policy systems are complex with power diffused across levels and possible policy choices develop in ongoing interactions between its separate parts. Changes in parts of the system are often also an expression of the dominant, institutionalized policy frames and knowledges [29,46]. Transformation often entails in-depth change challenging dominant rationalities and practices, but small changes can in the long-term lead to large-scale change in interconnected complex systems [39,42].

The first phase of this study involves mapping the municipal organizations and the ambitions of climate adaptation in terms of developments and strategies. Mapping the organization can be performed in various ways such as by studying how climate adaptation is related to systemic aspects, agency, and institutions [47]. This model does not necessarily include actual solutions and performative aspects as can be found in for instance the policy process or policy circle model relating to problem framing, policy formulation, decision-making, policy implementation, and policy evaluation (cf. [48]). By combining several of the above-mentioned aspects, the municipal organizations for climate adaptation are mapped and analyzed in four steps. The first step in this phase focuses on how the municipalities in question frame the climate adaptation problem. This is connected to what politicians and officials emphasize in their understanding of climate adaptation [31]. Differences in emphasis may result in different climate adaptation priorities and measures. The problem framing is directly related to how climate adaptation is prioritized among both politicians and officials in relation to other policy items and social challenges [29,49]. These aspects are closely connected to the second step of the analysis focusing on how key administrative and political actors relate to and work with climate adaptation, as the dominant problem framing also often entails the allocation of responsibilities from politicians to officials, which in turn leads to solutions that are formulated in a more limited context [50]. The third step focuses on the administrative and political structures, such as policies and plans, administrative positions, and the type of organization utilized. Earlier research for instance shows that climate adaptation plans can have many different forms but tend to be less concrete and dysfunctional as policy tools [51].

The fourth step focuses on specific climate adaptation measures and solutions. This connects organization to implementation as the structure of an organization determines how implementation works and what barriers can be identified. Organizational routines can hamper cross-sectoral measures highlighted in policy documents [52]. Research also shows that knowledge and ambition related to climate change adaptation typically rests with a few experts in the municipality and that this makes it difficult to expand implementation of measures to other sectors of the municipal organization [30].

The second, and more complex phase, analyzes climate adaptation from a learning and change perspective. To reach transformative change, learning has to be ongoing 
throughout the process, and in this study, we primarily focused on how active learning happens, both internally and externally. Hence, supporting our institutional perspective and reinforcing our analysis are theories on learning and experience feedback [53-55]. Two perspectives are key in our analysis. The first is adaptive learning, which concerns identifying and solving problems, but that does not question or challenge organizational aspects or primary goals, nor the fundamental values guiding action within the system. The other type of learning concerns demands of changes in organizational and steering models and modification of goals. This involves a more in-depth questioning of the way in which society handles climate adaptation from a broad holistic perspective and this type of learning can drive transformational change. The knowledge accumulated in relation to organizational learning also provides a basis for analyzing remaining barriers to change.

This gives us five focus areas that guide our analysis in Section 4:

- Problem framing;

- Administrative and political agency;

- Administrative and political structures;

- Measures and solutions;

- Learning.

\section{Materials and Methods}

\subsection{Research Design}

We performed semi-structured interviews with officials working with climate adaptation and conducted document studies in 13 municipalities (in this article we anonymized the municipalities and the region). In order to broaden the picture of municipal work within this area, semi-structured interviews were also conducted with officials from the Swedish Association of Local Authorities and Regions (SKR), the Swedish Meteorological and Hydrological Institute (SMHI), the Regional Organization, the County Administrative Board of the studied county, and the region.

We selected a Swedish region situated on the west coast of Sweden and studied regional and municipal climate adaptation policy and action within this region. Climate adaptation challenges in the 13 municipalities are to a great extent determined by their proximity to water - the ocean, lakes, and other watercourses - but several municipalities also have a landslide problem. The region in question comprises 12 municipalities and one municipality located in an adjacent county. These 13 municipalities form a common municipal association. Some of the municipalities are more rural in character, others are coastal communities, and one is a large city with all the challenges this involves.

\subsection{A Document Study}

The results of the study are based on two different types of material, the first is policy documents, especially designated as steering documents or directives. In some municipalities, these may include specific climate adaptation plans, but more often they are comprehensive plans, risk and vulnerability analyses, in-depth comprehensive plans, surface water plans, and consultants' reports. The documents have been used to create an overview of climate adaptation challenges in the municipality regarding risks related to nature and buildings and what measures have been taken, but also of the municipal structure in place for this work. Another important perspective concerns if and how learning is included as an explicit strategy in the documents. In some municipalities in our study there are no designated steering documents containing aspects of climate adaptation, but a process is ongoing to develop new documents, in this case a climate adaptation plan, and in other municipalities, the revision of the comprehensive plan is underway, where climate adaptation is included.

\subsection{Semi-Structured Interviews}

For the study, 18 semi-structured interviews were conducted with officials, including 13 in the municipalities in question, three at the regional level, and two at the national 
level (the Swedish Association of Local Authorities and Regions (SKR) and SMHI). For several interviews, two people were present, which meant that a total of 22 persons were interviewed. The selection of respondents was primarily based on whom the municipalities themselves indicated as responsible for, as a driving force in, or in other ways involved in, climate adaptation. The respondents had different kinds of positions, from planners in charge of local and comprehensive planning, to climate adaptation strategists and spatial planning managers. In cases where the municipality was not able to name a person working actively with climate adaptation, a comprehensive planner was selected. This variation in the roles of officials in the municipal hierarchy is in itself part of the result. It is also important to remember that there may be ongoing discussions regarding climate adaptation on other levels or in other sectors than the ones selected for interviews, but that these discussions are not yet generally recognized in the municipal organization. A local planner can have more detailed knowledge of ongoing climate adaptation in practice, while a person in a managerial position can know more about strategic decisions and principal standpoints.

Generally speaking, the selection of interviewees shows great variation in positions of persons perceived as most knowledgeable in, or who working most closely with, climate adaptation. A strict selection based on position was abandoned here in favor of the experiences of officials who pursue the issue or who work with it in practice. All respondents in the study were anonymized as the selection is based on roles and not on individuals. All translations of quotes were made by the authors.

As the purpose of the study was to map the municipal climate adaptation organization as well as aspects of learning, the questions in the interviews were quite broad. The questions were guided by the focus areas presented above under Section 2. Each semistructured interview was unique in the way follow-up questions related to the respondents different answers, roles, and experiences. Below, we present the main interview questions for each focus area.

Problem framing:

- How do the municipalities frame climate adaptation as a societal problem both on the local, national, and global level?;

- What are the main challenges in relation to climate adaptation?

Administrative and political agency:

- What is the role of local politics in the climate adaptation?;

- Is climate adaptation a prioritized issue?;

- Who are the key actors working with climate adaptation?

Administrative and political structures:

- What are the most important national laws and guidelines, and are these in need of improvement?;

- What kind of administrative processes and structures are related to climate adaptation?

Measures and solutions:

- Are any policy documents and/or action plans developed?;

- Is there a specific climate adaptation plan, and if so, how is it used?;

- Is climate adaptation integrated into the comprehensive planning, and if so, how?;

- What are the main measures and solutions regarding climate adaptation and who is responsible for the implementation?;

- What does the internal climate adaptation coordination look like?;

- What external actors are the municipality cooperating with and in what way? Learning:

- How does the municipality incorporate new knowledge and how does the municipality disseminate its own good practices?;

- What are the main challenges for climate adaptation moving forward? 
The respondents on the national level were also asked to reflect upon these issues but they were, in addition, asked to discuss national policies, laws, and debates.

\section{Organization for Climate Adaptation}

An overview of how the municipalities in question work with climate adaptation follows below. It starts with a description of what role general support and guidelines play in the municipalities. Thereafter it proceeds to analyze how climate adaptation is framed and discussed in municipal administration and politics, who the key actors are and how they relate to climate adaptation, what kind of climate adaptation structure is in place, and what measures are developed and implemented.

In addition to their own documents and action plans, the municipalities are affected by guidelines at the national and regional levels. The respondents in the present study point out that they use different types of guidelines differently. First of all, current legislation for various areas, such as the Planning and Building Act, is centrally important. For this reason, the National Board of Housing, Building and Planning plays an important role in helping municipalities interpret legislation in relation to climate adaptation. In this context, many respondents claim that climate adaptation has been focused on observing current legislation and guidelines.

The national risk and vulnerability inquiry from 2007 [56] highlighted the challenges that Sweden faced. The inquiry stated that immediate and concrete measures were required and that considerable resources needed to be allocated to climate adaptation in both the short and the longer term. The County Administrative Board was given a coordinating role. The current Swedish government's ambitions in this area are expressed in the National Strategy for Climate Adaptation [57]. The central aims of the strategy are to present guidelines for strengthened coordination and clarify the division of responsibilities, and to provide support in future measures and priorities. The municipalities also have an important role locally and, above all, in planning issues. The Swedish Meteorological and Hydrological Institute (SMHI) has, in its assignment to be a national knowledge center, developed guidelines to support Swedish municipalities' climate adaptation [58] and to produce broad knowledge base on climate adaptation. Swedish municipalities can also find knowledge and support from the interest organization, the Swedish Association of Local Authorities and Regions (SKR). The Swedish Geological Survey (SGU) is the authority that Swedish municipalities can turn to regarding issues concerning rocks, soil, and groundwater. The National Board of Housing, Building and Planning can support with advice on legislation in the planning and construction area. The Swedish Environmental Protection Agency can provide support for ecosystem services and green infrastructure. In addition to support from authorities at state and regional level, it is also common for municipalities to hire consulting firms to carry out various types of surveys that will provide a basis for continued climate adaptation. Last but not least, many Swedish municipalities participate in various types of national and international networks for knowledge and experience transfer in the area.

Hence, the national strategy stresses that the municipalities' work with climate adaptation is central to taking the next step in implementing the changes required to create a robust and sustainable society [57]. This places great demands on the municipal organization as well as its strategies, policies, and measures. Although the municipalities has been active in climate adaptation for many years, several studies show that the work has been rather slow and that Swedish municipalities have had a tendency to work within existing structures rather than creating new ones [32]. In addition, the conditions for the Swedish municipalities vary to a great extent and small municipalities can find climate adaptation demanding and problematic.

Despite this national mobilization, the municipalities have waited for explicit guidance and clarity regarding what authority/authorities is/are expected to pursue the issue of climate adaptation. Thus, the respondents welcome the designation of the County Administrative Board as playing an important role in the Climate Report, and the ongoing 
work at the County Administrative Board is highlighted as an important reason why more and more municipalities in the county are working more actively with climate adaptation. This has been done in a number of different ways, but the 2017 action plan of the County Administrative Board is particularly emphasized [59]. However, several respondents argue that the County Administrative Board should be even more active in pursuing the issue, especially in relation to certain municipal actors, such as managers and politicians. This is what two respondents say about the role of the County Administrative Board;

I think they should require a focus on climate adaptation and in that sense be a bit more demanding. They are trying to inspire us and encourage us through various missives and so on, but they have not really been successful, at least not at the managerial level [60].

And we feel as though this is spurring us on a bit, I guess, it is one of the things that made us decide to go for this service now as well [61].

When asked if more legislation is required in the area, a majority of respondents say that they have not really seen a need for that. However, there are exceptions;

... from our side [in the municipality], we would indeed have wanted to see the legislation adjusted as regards how to distribute responsibility and also resources [62].

The framing of climate adaptation on the national level has implications for how the issue is discussed and framed on the local level in terms of urgency, prioritization, resources, and knowledge.

\subsection{Framing the Problem}

Both politicians and authorities at the national level have been criticized for not discussing climate adaptation enough. Making the matter more of a priority on the national agenda could, according to the respondents, encourage more local politicians to show interest in and make a priority out of the issue, but it depends largely on how the problem is framed on both global, national, and local levels.

Climate adaptation is described in two different ways by the respondents participating in the study; first, as a major global challenge for society that all sectors must be prepared to handle, and second, as related to concrete challenges for the municipality in question, such as a frequently flooded watercourse. Most of the time, climate adaptation is described in one out of these two ways.

Those who describe climate adaptation as a more general societal challenge identify it as a problem that the issue has not been emphasized enough at the national level, which is also reflected at the local level. They point out that it is unclear who is ultimately responsible and who will cover the cost, not only to adapt new buildings but also to adapt existing structures.

Those who describe climate adaptation in relation to local circumstances in a municipality primarily start out from concrete events or risks, and then identify organizational problems, such as who is responsible for the issue of climate adaptation in the municipality and how the work is coordinated. In addition, the fact that the matter has not been made more of a priority at the local level either is criticized by the respondents, at the same time as officials in different ways express self-criticism for not having focused enough on the issue.

In municipalities that have not worked much with climate adaptation, it is noticeable that the description of the work is somewhat vague and sometimes included in climate measures generally. A certain hesitation in relation to the issue can be discerned.

There is, however, a consensus among all respondents that people used to think that climate adaptation work equals giving up on the effort to counter climate change, but that attitude is becoming increasingly rare. According to the respondents, there is an awareness that municipalities have to work with both climate adaptation and measures to reduce emissions at the same time. 
Climate change will continue even if human impact on the climate decreases, for instance when we choose other ways to travel or heat our homes. This may mean that the pace of climate change slows down, not that climate change is avoided [63].

\subsection{Administrative and Political Agency}

A majority of respondents said that climate adaptation is not a particular priority among the politicians in the municipality. One of the respondents gave a rather representative answer:

I don't think the issue is prioritized. We have had a right-wing administration for a very long time in [the municipality] the minimum municipality tax [ ... ] which means they pretty much want to minimize things. If we were to have a new administration, I can guarantee that there would be some more resources for this particular type of issue [61].

There are exceptions, where the issue has been included from the beginning, such as in particular events or administrative processes, for instance in ongoing comprehensive plan processes, or in developing a climate adaptation plan. Several respondents talked about a slow but increasing consensus in the municipality regarding the importance of working more concretely with climate adaptation.

It is almost stressful now how everyone keeps pushing and saying that we have to get started, and this is also related to the fact that we are growing which means that very many plans are underway [64].

However, a majority of respondents were explicit about a political and ideological perspective on climate and environmental issues that make more right-leaning parties and the Sweden Democrats likely to prioritize and discuss growth and new buildings, while red and green coalitions also more frequently include climate and environmental issues in their budgets.

Several respondents reasoned around different types of strategies for making the issue part of the agenda. The respondents mentioned that they had to adjust their way of presenting or pursuing climate adaptation issues to the political majority in the municipality. For instance, one respondent pointed out that it is not possible to use just any municipality as an example; instead, it is more strategic to pick examples from "right-leaning" municipalities when there is a "right-leaning" political majority and vice versa.

My purpose is to convince politicians and also officials for that matter that this is an important issue. [ ... ] But it is easier, however, to make our politicians pay attention to something that a right-leaning municipality has done, and those examples are sort of highlighted [65].

We have to work harder [if there is a right-leaning majority] to highlight why it is important and how it will in fact benefit them in the end, in terms of planning, that in the long term it is more advantageous [66].

Another way of working strategically to make climate adaptation an item on the agenda is to find support in the global goals and broad collaborations with other municipalities and regional and national actors. One official said the following:

We have come very far in terms of aiming for and working towards the global goals, so the municipal operational plan is sort of based on that now ... to stick to this holistic view, this idea of sustainability ... sitting with the municipal commissioners and trying to identify the criteria that we have to consider anyway since they are long-term, the global goals. [ ... ] This in turn provides support in relation to the political level that these municipalities are all working together now to do this [64].

Not everyone is comfortable with ending up in a driving role in the process, however, but due to what they consider to be political quiescence, they have realized that it is part 
of the expert role that an official may take. "I guess it may seem like activism, but some things need to be done that are not going to be popular politically, you know" [67].

All respondents claimed that it is primarily officials in different positions that pursue and are expected to pursue the issue of climate adaptation, but this is not necessarily the case for all climate-related or environmental matters. Since climate adaptation is a relatively new concern at the municipal level in practice, several respondents expressed an understanding that it has not yet turned into a clear-cut political issue.

\subsection{Administrative and Political Structures}

In most of the 13 municipalities, the respondents claimed that each department should be responsible for their part of the climate adaptation issue, but that this is rarely reflected in the organizational set-up. This is particularly true for the implementation of climate adaptation measures. The most common model by far is that the climate adaptation issue is pursued most actively in the spatial planning sector. Climate adaptation is often an integral part of both comprehensive plans and local plans. The respondents mainly mentioned climate adaptation in relation to guidelines for new buildings when it comes to elevation, what is usually called "rising water". According to the respondents, few municipalities have introduced active climate adaptation measures in all sectors, so-called mainstreaming. On the other hand, it became more and more obvious as the interview study progressed, going into a period of a heatwave in the early summer of 2018, that climate adaptation was increasingly on the agenda. It is also clear that municipalities with an organizational set-up working with climate adaptation at the central level, which is discussed below, have been able to achieve more cross-sectoral collaboration than other municipalities.

Few municipalities have a designated person working as a climate adaptation coordinator or similar with a specific assignment to have a comprehensive view of what is being done. When asked if a specified coordinating function is needed, most respondents answered that it would of course be positive, but not absolutely necessary. Coordination could be done in several different ways. One of the respondents argued that:

There is a great deal of expertise that we need to get from different departments, so I think that at this particular moment, because of our organization, a team might suit us better than a specific person [66].

Those who have instituted or are about to institute a function like this said that it may be crucial at this particular time and for climate adaptation specifically to develop coordination between sectors and to make sure that all sectors work with the issue in the first place.

It is not like there is a coordinator for all issues, we think that this particular issue demands it at this stage [62].

One municipality has for example chosen at the time of the study to have an employee handling climate adaptation at 50 per cent and other climate-related issues at 50 per cent. Even though there are slightly different needs when it comes to a particular position as climate adaptation coordinator, all respondents agreed that coordination is crucial for the continued effort. In the current comprehensive plan for Municipality 1, for instance, a recent decision is that; "Responsibility for coordination [of climate adaptation issues] will be assigned as a follow-up task of this comprehensive plan" [68], and furthermore some kind of climate adaptation plan will be developed.

One way of initiating climate adaptation in a municipality is to develop a particular climate adaptation plan or make sure that climate adaptation is an explicit part of some other ongoing policy effort. It is seen as especially relevant that a specific assignment for this is given by the politicians. By the time of the study, three of the municipalities have a climate adaptation plan or are performing ongoing work to develop one. In at least three of the other municipalities, it is explicitly stated in policy documents, such as risk and vulnerability analyses or the comprehensive plan, that the municipality should develop a climate adaptation plan. When asked if there is a need for a particular climate adaptation 
plan, a majority of respondents answered that this it is not entirely necessary. However, everyone underlined the importance of including the issue in a current policy document, and of having a functional organization for climate adaptation. One respondent said:

We see that there is a great need for that, but I think that it may be the second step, since first we probably need this organizational aspect [66].

Several respondents also said that a plan must be a living document in order to be beneficial. It is not helpful just to create a document which will only be on paper and nothing more. The plan itself is not necessarily the most crucial part of climate adaptation, but what happens while it is being drafted and later on. One respondent said that:

... it is OK that it takes time since it is not the plan itself that is important, but rather the process for us to bring everyone along and create an understanding of how we are going to work [64].

In most municipalities, the climate adaptation issue has been included in other types of documents, such as risk and vulnerability analyses, surface water plans, and similar. All respondents from the 13 municipalities said that climate adaptation is a key part when developing new comprehensive plans. For this reason, many of them did not think that particular climate adaptation plans are required. Many of the municipalities in the present study are in the middle of comprehensive plan development work, and this work has among other things been affected by the effort made by the County Administrative Board to promote the issue of climate adaptation. Generally speaking, the respondents are uncertain about what other steering documents could be relevant for climate adaptation in their own municipality. A summary of the municipal organization for climate adaptation work follows in Table 1 below. The table is based on information given by the municipalities in connection with the interviews conducted in the spring of 2018. The municipalities may have revised their work since then, or progressed further in various processes.

Table 1. Summary of climate adaptation organization in the municipalities (Spring 2018).

\begin{tabular}{|c|c|c|c|c|c|}
\hline & $\begin{array}{c}\text { Climate Adaptation } \\
\text { Plan or Similar, } \\
\text { Completed or in } \\
\text { Progress }\end{array}$ & $\begin{array}{l}\text { Centrally Appointed } \\
\text { Climate Adaptation } \\
\text { Coordinator/Strategist } \\
\text { Full-Time/Part-Time }\end{array}$ & $\begin{array}{l}\text { Climate Adaptation } \\
\text { included in } \\
\text { Comprehensive Plan } \\
\text { Development }\end{array}$ & $\begin{array}{l}\text { Political } \\
\text { Governance } \\
2014-2018\end{array}$ & $\begin{array}{c}\text { Started Central } \\
\text { Systematic Work } \\
\text { across Several } \\
\text { Sectors } \\
\text { (Mainstreaming) }\end{array}$ \\
\hline Municipality 1 & & & & $\begin{array}{l}\text { Center-right majority } \\
\text { coalition }\end{array}$ & \\
\hline Municipality 2 & & & & $\begin{array}{l}\text { Left-center majority } \\
\text { coalition }\end{array}$ & \\
\hline Municipality 3 & & & & $\begin{array}{l}\text { Center-right majority } \\
\text { coalition }\end{array}$ & \\
\hline Municipality 4 & & & & $\begin{array}{l}\text { Center-right coalition, } \\
\text { no majority }\end{array}$ & \\
\hline Municipality 5 & & & & $\begin{array}{l}\text { Left-center majority } \\
\text { coalition }\end{array}$ & \\
\hline Municipality 6 & & & & $\begin{array}{c}\text { Left-center coalition, } \\
\text { no majority }\end{array}$ & \\
\hline Municipality 7 & & & & $\begin{array}{c}\text { Center-right coalition, } \\
\text { no majority }\end{array}$ & \\
\hline Municipality 8 & & & & $\begin{array}{l}\text { Center-right majority } \\
\text { coalition }\end{array}$ & \\
\hline Municipality 9 & & & & $\begin{array}{l}\text { Left-center majority } \\
\text { coalition }\end{array}$ & \\
\hline $\begin{array}{l}\text { Municipality } \\
10\end{array}$ & & & & $\begin{array}{c}\text { Center-right majority } \\
\text { coalition }\end{array}$ & \\
\hline $\begin{array}{l}\text { Municipality } \\
11\end{array}$ & & & & $\begin{array}{l}\text { Left-center majority } \\
\text { coalition }\end{array}$ & \\
\hline $\begin{array}{l}\text { Municipality } \\
12\end{array}$ & & & & $\begin{array}{l}\text { Left-center majority } \\
\text { coalition }\end{array}$ & \\
\hline $\begin{array}{c}\text { Municipality } \\
13 \\
\end{array}$ & & & & $\begin{array}{l}\text { Left-center majority } \\
\text { coalition }\end{array}$ & \\
\hline
\end{tabular}




\subsection{Measures and Solutions}

Municipalities that have climate adaptation plans also have much more systematic and well-organized measures, at least on paper. According to several respondents, it is important to distinguish between different types of measures.

... on the one hand we have organizational, steering measures, information and consciousness-raising measures, and on the other hand we have measures that involve "building things" or "planning things". And these things have to be done at the local level, but ... the framework for them ... must be supplied at the national level [60].

The climate adaptation measures that have been implemented in the municipalities in question so far can be categorized broadly in terms of prevention on the one hand and crisis management on the other. The preventive measures include most of the climate adaptation efforts in the municipalities, and several measures can be connected to organizational change or organizational clarity. The climate adaptation plan for Municipality 13 states that, "Some measures involve for instance creating structures and routines for day-to-day operations" [63].

Many measures concern investigation, mapping, and review. One example can be found in Municipality 12, where there is a recommendation to map how increasing temperatures can be handled in elderly care and childcare [69].

Another category of measures concerns increased supervision and control of various areas, such as surface water or systems for measuring water levels. Most measures that are more specific tend to be connected to spatial planning issues, and especially aspects of comprehensive plans and local plans, such as climate-adapted floor elevation for new buildings (cf. [70]) or the marking of hazardous areas and buildings in comprehensive plans (cf. [71]).

However, several of the municipalities in the study have regularly had to deal with floods and landslides, in particular, which require more urgent crisis management measures. In those cases, mainly the emergency services are contacted, and if the municipality has some kind of security coordinator, that person is typically in charge of risk management. In addition, specific municipal personnel responsible for water and sewage issues are involved in connection with the urgent situation. The respondents expressed some selfcriticism, saying that while measures may be implemented in accordance with crisis plans, there is no natural link between crisis management and climate adaptation efforts in the short or long term.

The respondents said that climate adaptation measures are primarily implemented in spatial planning matters, where the most progress has been made in terms of concrete activities. Apart from those, it is mostly a question of analyzing, mapping, and investigating various needs in preparation for a more systematic climate adaptation in all sectors, something that all respondents agree will be necessary.

For instance, in one municipality, the measures are divided into four categories; governing measures, health measures, building and infrastructure measures, and environmental and nature protection measures, and the climate adaptation plan has a broad cross-sectoral ambition. Hence:

The [climate adaptation] effort requires a well-functioning cooperation in and between the different units and sectors of the municipality. Resources in the form of financial resources, personnel, and competence have to be made available for the administration and this is often an issue related to budget and operational plan ([63], p. 7).

\subsection{Learning}

In this section, the respondents' views of learning and networking related to climate adaptation are described. External learning can happen in many different ways; through support and a knowledge base obtained from the authorities, through finding out about 
research on the issue, through taking part in different types of networks, and through contact with other municipalities. Learning can also happen internally, through learning from previous events and learning from other departments. This section outlines how the 13 municipalities work actively with learning, but also how the respondents reflected upon more informal processes of learning.

\subsubsection{Learning in Networks and External Collaboration}

In the regional collaborative framework, there are several networks where climate adaptation is part of the agenda. Among other things, there is a collaborative project on watercourses and coastlines. A network focused on climate adaptation is in the process of being introduced as part of the collaboration in the municipal association at the time of the study, and the municipalities in the study welcomed this type of network not only as beneficial for their own work, but also since collaboration within the municipal association is politically grounded.

We would need the issue to be highlighted at the regional level, since that would make it more obvious for the politicians that we have to ... because many of them are also in these different political positions in the region, and it would make them aware, in order to give an assignment [60].

Several municipalities also participate in a regional research collaboration, which primarily allows them to exchange knowledge in seminars and workshops. There are other types of seminars as well, for instance those hosted by the County Administrative Board. In addition, there are other projects, such as EU projects and projects in collaboration with national agencies such as SMHI and the Environmental Protection Agency, which often involve several municipalities. Many respondents mentioned the new SMHI reference guide [36], but few have started using it. The Swedish Civil Contingencies Agency (MSB) was also mentioned by a number of respondents as an increasingly important supplier of knowledge and support. But there were also some respondents who did not find the support of these agencies adequate, and who said that they:

... do not have a lot of agency in terms of doing things; they can present, sort of display reports and a knowledge base, but perhaps we need to move on to a situation where we operationalize much more [62].

More spontaneous exchanges of knowledge occur as well between municipalities, but due to the fact that there are established networks in place, those networks are primarily where knowledge and experiences are shared. Several municipalities have close collaborations with their immediate municipal neighbors, usually with regards to specific watercourses. In general, the respondents were very positive towards cooperation for various purposes.

I think it's good, maybe for us and other small municipalities finding it difficult to have our/their own expertise in all areas that we have been assigned to work on. It can mean a great deal in those cases to have networks and that there is knowledge at the central level [61].

The size of a municipality is an aspect that respondents mentioned as a reason for why climate adaptation is not always a prioritized issue. There have been strategic grounds for waiting a while before making organizational changes and implementing further measures, since it is possible to save both time and resources in learning from other municipalities.

We have in fact tried to signal that we need someone to look into these issues, you know, since it does not seem as though they have been recognized so far ... it has always been the case that we are supposed to wait and see what others are doing, since we are a small municipality [60].

What is it, then, that the municipalities learn from these collaborations and how does that knowledge become integrated in the internal work of each municipality? According to the respondents, it is usually a question of concrete methods and measures. Few 
respondents, however, said that there is an explicit method for officials to bring back knowledge and implement it in their own municipality. It is not a systematic effort.

Networks are considered important, but tend to be less of a priority when many other things have to be done. On the other hand, some respondents said that collaborations and networking sow seeds that introduce new ideas into the organization and rock the organizational boat. Many of the municipalities in the study are at a formative stage of climate adaptation, and they are interested in how others have chosen to do it. These respondents wanted to know:

... how others work in their organizations ... who is responsible for what and

... also if they have developed strategic documents [66].

This formative stage that many of the municipalities in question are in creates a certain openness regarding knowledge about the best practice and best organization for working with climate adaptation. This in turn may mean that municipalities have to be innovative and think in general and strategic terms.

I think it's a question of having a shared view of the situation, an approach to ... this common challenge and the fact that we have to tackle it together. This means that ... these municipal boundaries do not exist, the water runs its course regardless and we have to work together on these issues [72].

\subsubsection{Internal Learning}

Another way of analyzing learning is to study what a municipality learns from different local events and crises. Many of the municipalities in the study have handled floods and landslides over the years. Many respondents were explicitly self-critical when analyzing how that knowledge has been used. They say that it was incorporated in the continued work directly after the events, but rarely in a systematic manner for the long term, and moreover not clearly related to other climate adaptation efforts. One of the respondents said:

We learnt something from the consequences of what happened then ... but maybe we did not imagine that there might be a risk for similar problems in other parts of the municipality, so instead we tried to prevent that particular event from happening again. [ ... ] My experience is that it hasn't resulted in any significant change of strategy in relation to climate change, I don't think [72].

Other respondents, however, pointed out that it is possible to work with internal learning aimed at the long term, when it is not only a question of learning something limited in relation to the present moment and one sector. Thus, different municipalities have handled the aftermath of an emergency in different ways.

We have learnt a very great deal from it and we have done so extensively. We created a group afterwards including spatial planning, and also technicians and the water and sewage department and street department, where we discussed everything related to the knowledge that we had acquired and then over a number of years ... we implemented an enormous number of measures [73].

Since few of the municipalities in question had started working on climate adaptation in an explicit, systematic, and cross-sectoral way, it is difficult to assess on the basis of the present study what a possible instance of cross-sectoral learning might look like. We can see that a number of challenges arise when such learning is expected to happen.

Each sector is good at working on their own issues ... we try to get input from others, like having someone there who is working in support and care but ... my take on it so far is that we're not really involving the people we want to have input from or initiate a conversation at the right moment for people to be able to and want to receive feedback [74].

It is in discussions of cross-sectoral work that many respondents' expressed interest in instituting some kind of coordinating function. It is complicated to learn across sectoral 
boundaries, especially if certain sectors have not yet established climate adaptation as an explicit and prioritized issue. If that is the case, distinct coordination helps.

\section{Concluding Remarks}

It is clear that there are specific barriers explaining why climate adaptation has not been prioritized in the municipal organization, in political debate, or in policy development in several of the municipalities studied here. Our study show that different actors and organizations have different opinions regarding whether climate adaptation should be given high political priority in relation to other pressing policy issues. This means that one barrier is the lack of political will to prioritize climate adaptation and this is also connected to the scarce knowledge among municipal politicians about the importance of climate adaptation and the difference in approaches in relation to climate mitigation. This has led to a sometimes involuntary activist role of employees working with climate adaptation and the development of strategies to promote the issue. As a result of being less prioritized, climate adaptation has had a shortage of resources such as permanent positions working with the issue, in creating strategic documents, as well as implementing measures. This has been particularly problematic for smaller municipalities. One modus operandi from the County Administrative Board has been to promote the development of climate adaptation plans hoping for an organization forming around that work. In relation to the lack of resources, the possibility to build an organization based on knowledge and best practice is limited. A third barrier to progress has been a lack of clear and explicit political signals from the national level and from responsible authorities, either formally in terms of legislation or informally in terms of opinion-forming activities. Hence, municipal actors perceive that there is a lack of clarity from national authorities concerning recommendations on how to work concretely but also on the legal grounds for more proactive climate adaptation. The role of the County Administrative Board has been made clearer but other roles remain quite blurred.

Our study showed that climate adaptation seems to be well established in comprehensive and local plans. It is plausible that efforts from the County Administrative Board, and other public actors, in guiding and encouraging municipalities to include climate adaptation actively in their comprehensive plans is one driver of this development. We can also observe that specific climate adaptation plans are being developed. This can have a positive effect on attempts to introduce coordinating functions in relation to climate adaptation, but it is not always the plan itself that matters but the process and the learning that the process facilitates.

Climate adaptation is cross-cutting and affects many municipal sectors, and our respondents found the specific coordinating efforts both within the municipality and with other actors encouraging, and many were also positive regarding the creation of particular positions, such as climate adaptation strategists. At present, there are only a few experts on climate adaptation in each of the studied municipalities which can lead to increased vulnerability. To decrease vulnerability in several sectors (planning, technological, health, social, etc.) simultaneously, the coordination of resources is crucial. However, there is a risk that establishing a permanent coordinating position might be the only dedicated resource allocated in the municipal budget, while efforts and resources are required to create cross-sector collaboration that can introduce climate adaptation in all sectors.

At the same time, we can observe how learning takes place in all sectors of the municipality and that there is a great interest in taking part in networks with other municipalities to facilitate exchange of experiences and further learning processes. Networking is also primarily where the respondents identify a significant potential for learning. One aspect that emerges as particularly important is the need to create a regional network dedicated to climate adaptation, something that did not exist when the study was carried out.

Several respondents pointed out that the municipalities are at a stage where they need be innovative in relation to climate adaptation. They need to go back to basics and there are questions regarding whether the current organization has the capacity to 
address the challenges from a changing climate and its impacts. Our study show that several respondents learn from experiences in other municipalities on traditional "simple" measures (concrete flood protection measures, etc.) that are implemented within the framework of the existing organization of climate adaptation, but the respondents also identified the need for more extensive organizational change which demands thinking "outside the box" and that puts climate adaptation into its wider societal setting. This might indicate that our respondents were, at least in part, approaching transformational learning.

In conclusion, we acknowledge that the studied municipalities are still at a formative stage of climate adaptation and that organizational and governance models generally have not yet been fully developed and/or institutionalized. In order to reach the next stage of development, the municipalities need increased coordination between sectors, increased learning, clearer political prioritization of climate adaptation that involves the allocation of more resources, and, finally, a serious overview of the of the current municipal organization's suitability for adaptation to the current and future impacts of climate change.

Author Contributions: A.-C.K. worked on the data collection. Both authors worked on the conceptualization, analysis, and writing. All authors have read and agreed to the published version of the manuscript.

Funding: This research was funded by Länsförsäkringsbolagens Forskningsfond, grant number P2/14, and the research fund of the Swedish Civil Contingency Agency, grant number MSB/2016-6855.

Institutional Review Board Statement: Ethical review and approval were waived for this study, due to the non-sensitive character of the content of the interviews.

Informed Consent Statement: Informed consent was obtained from all subjects involved in the study.

Acknowledgments: The authors would like to thank the two anonymous reviewers for their valuable comments. The authors are also grateful for the support received from the Centre for Societal Risk Research, Karlstad University, Sweden.

Conflicts of Interest: The authors declare no conflict of interest. The funders had no role in the design of the study; in the collection, analyses, or interpretation of data; in the writing of the manuscript; or in the decision to publish the results.

\section{References}

1. IPCC. Global Warming of $1.5^{\circ} \mathrm{C}$; IPCC (Intergovernmental Panel of Climate Change): Geneva, Switzerland, 2019.

2. IPCC. Climate Change 2014: Impacts, Adaptations and Vulnerability; Cambridge University Press: Cambridge, UK, 2014.

3. IPCC. Managing the Risks of Extreme Events and Disasters to Advance Climate Change Adaptation: Special Report of the Intergovernmental Panel on Climate Change; Cambridge University Press: Cambridge, UK, 2012.

4. Sovacool, B.K. Bamboo beating bandits: Conflict, inequality, and vulnerability in the political ecology of climate change adaptation in Bangladesh. World Dev. 2018, 102, 183-194. [CrossRef]

5. Vij, S.; Moors, E.; Ahmad, B.; Arfanuzzaman, M.; Bhadwal, S.; Biesbroek, R.; Gioli, G.; Groot, A.; Mallick, D.; Regmi, B.; et al. Climate adaptation approaches and key policy characteristics: Cases from South Asia. Environ. Sci. Policy 2017, $78,58-65$. [CrossRef]

6. Shaffril, H.A.M.; Ahmad, N.; Samsuddin, S.F.; Abu Samah, A.; Hamdan, M.E. Systematic literature review on adaptation towards climate change impacts among indigenous people in the Asia Pacific regions. J. Clean. Prod. 2020, 258, 120595. [CrossRef]

7. Baja, K.; Granberg, M. From engagement to empowerment: Climate change and resilience planning in Baltimore city. In Local Action of Climate Change: Opportunities and Constraints; Moloney, S., Fünfgeld, H., Granberg, M., Eds.; Routledge: London, UK, 2018; pp. 126-145.

8. Olazabal, M.; de Gopegui, M.R.; Tompkins, E.L.; Venner, K.V.; Smith, R. A cross-scale worldwide analysis of coastal adaptation planning. Environ. Res. Lett. 2019, 14, 124056. [CrossRef]

9. Cramer, W.; Guiot, J.; Fader, M.; Garrabou, J.; Gattuso, J.-P.; Iglesias, A.; Lange, M.A.; Lionello, P.; Llasat, M.C.; Paz, S.; et al. Climate change and interconnected risks to sustainable development in the Mediterranean. Nat. Clim. Chang. 2018, 8, 972-980. [CrossRef]

10. Thomas, K.; Hardy, R.D.; Lazrus, H.; Mendez, M.; Orlove, B.; Rivera-Collazo, I.; Roberts, J.T.; Rockman, M.; Warner, B.P.; Winthrop, R. Explaining differential vulnerability to climate change: A social science review. Wiley Interdiscip. Rev. Clim. Chang. 2019, 10, 18. [CrossRef] [PubMed]

11. Moloney, S.; Fünfgeld, H.; Granberg, M. (Eds.) Local Action on Climate Change: Opportunities and Constraints; Routledge: London, UK, 2018. 
12. Glover, L.; Granberg, M. The Politics of Adapting to Climate Change; Palgrave Macmillan: London, UK, 2020.

13. Lovecraft, A.L. Climate change and arctic cases: A normative exploration of social-ecological systems analysis. In Politcal Theory and Global Climate Change; Vanderheiden, S., Barry, J., Eds.; The MIT Press: Cambridge, MA, USA, 2008; pp. 91-120.

14. Farber, D.A. Issues of scale in climate governance. In The Oxford Handbook of Climate Change and Society; Paperback, J.S., Dryzek, R., Norgaard, B., Schlosberg, D., Eds.; Oxford University Press: Oxford, UK, 2013; pp. 479-489.

15. Bulkeley, H. Cities and subnational governments. In The Oxford Handbook of Climate Change and Society; Paperback, J.S., Dryzek, R., Norgaard, B., Schlosberg, D., Eds.; Oxford University Press: Oxford, UK, 2013; pp. 464-478.

16. Agrawal, A.; Kononen, M.; Perrin, N. The Role of Local Insititutions in Adaptation to Climate Change; The World Bank: Washington, DC, USA, 2009; p. 23.

17. Jensen, A.; Nielsen, H.Ø.; Russel, D. Climate Policy in a Fragmented World-Transformative Governance Interactions at Multiple Levels. Sustainability 2020, 12, 17. [CrossRef]

18. IFRC. World Disaster Report 2020: Come Heat of High Water; International Federation of Red Cross and Red Crescent Societies: Geneva, Switzerland, 2020.

19. Moloney, S.; Fünfgeld, H.; Granberg, M. Climate change responses from the global to the local scale: An overview. In Local Action on Climate Change: Opportunities and Constraints; Moloney, S., Fünfgeld, H., Granberg, M., Eds.; Routledge: London, UK, 2018; pp. $1-16$.

20. Castán Broto, V.; Robin, E.; White, A. (Eds.) Climate Urbanism: Towards a Critical Research Agenda; Palgrave Macmillan: London, UK, 2020.

21. Gaillard, J.-C.; Mercer, J. From knowledge to action: Bridging gaps in disaster risk reduction. Progress Hum. Geogr. 2013, 37, 93-114. [CrossRef]

22. Moloney, S.; Fünfgeld, H.; Granberg, M. Towards transformative action: Learning from local experiences and contexts. In Local Action on Climate Change: Opportunities and Constraints; Moloney, S., Fünfgeld, H., Granberg, M., Eds.; Routledge: London, UK, 2018; pp. 146-156.

23. Norris, F.H.; Stevens, S.P.; Pfefferbaum, B.; Wyche, K.F.; Pfefferbaum, R.L. Community Resilience as a Metaphor, Theory, Set of Capacities, and Strategy for Disaster Readiness. Am. J. Community Psychol. 2008, 41, 127-150. [CrossRef]

24. Sharifi, A.; Chelleri, L.; Fox-Lent, C.; Grafakos, S.; Pathak, M.; Olazabal, M.; Moloney, S.; Yumagulova, L.; Yamagata, Y. Conceptualizing dimensions and characteristics of urban resilience: Insights from a co-design process. Sustainability 2017, 9, 1032. [CrossRef]

25. Montin, S.; Granberg, M. Moderna Kommuner; Liber: Stockholm, Sweden, 2021.

26. Proposition 2017/18:163. In National Strategy for Climate Adaptation; The Swedish Government: Stockholm, Sweden, 2013.

27. Pierson, P. The New Politics of the Welfare State; Oxford University Press: Oxford, UK, 2001.

28. Lidskog, R.; Elander, I. Ecological Modernization in Practice? The Case of Sustainable Development in Sweden. J. Environ. Policy Plan. 2012, 14, 411-427. [CrossRef]

29. Granberg, M.; Nyberg, L. Climate change adaptation, city competiveness and urban planning in the city of Karlstad, Sweden. In Local Action of Climate Change: Opportunities and Constraints; Moloney, S., Fünfgeld, H., Granberg, M., Eds.; Routledge: London, UK, 2018; pp. 111-125.

30. Storbjörk, S. 'It Takes More to Get a Ship to Change Course': Barriers for Organizational Learning and Local Climate Adaptation in Sweden. J. Environ. Policy Plan. 2010, 12, 235-254. [CrossRef]

31. Uggla, Y.; Storbjörk, S. Klimatrisker på planerarnas agenda: Att hantera motstridiga krav och kunskapsosäkerhet. Dan. Sociol. 2012, 23, 73-95. [CrossRef]

32. Hjerpe, M.; Glaas, E.; Storbjörk, S.; Jonsson, A.C.; Brink, E.; Wamsler, C. Svensk Forskning om Klimatanpassning och Planering; Centrum för Klimatpolitiskforskning, Linköpings Universitet: Linköping, Sweden, 2014.

33. Roth, S.; Thörn, P. Klimatanpassning—Så Långt har Kommunerna Kommit; IVL Svenska Miljöinstitutet: Stockholm, Sweden, 2015.

34. Thörn, P.; Ekholm, H.M.; Nilsson, Å. Klimatanpassning 2017—Så Långt har Kommunerna Kommit. Enkätundersökning och kommunranking; IVL Svenska Miljöinstitutet: Stockholm, Sweden, 2017.

35. Pelling, M. Adaptation to Climate Change: From Resilience to Transformation; Routledge: London, UK, 2011.

36. Bosomworth, K.; Leith, P.; Harwood, A.; Wallis, P.J. What's the problem in adaptation pathways planning? The potential of a diagnostic problem-structuring approach. Environ. Sci. Policy 2017, 76, 23-28. [CrossRef]

37. Rickards, L. Transformation is adaptation. Nat. Clim. Chang. 2013, 3, 690. [CrossRef]

38. Granberg, M.; Bosomworth, K.; Moloney, S.; Kristianssen, A.-C.; Fünfgeld, H. Can Regional-Scale Governance and Planning Support Transformative Adaptation? A Study of Two Places. Sustainability 2019, 11, 6978. [CrossRef]

39. Wagenaar, H. Meaning in Action: Interpretation and Dialogue in Policy Analysis; M.E. Sharpe: Armonk, NY, USA, 2011.

40. Hölscher, K. Capacities for transformative climate governance: A conceptual framework. In Transformative Climate Governance: A Capacities Perspective to Systematise, Evaluate and Guide Climate Action; Hölscher, K., Frantzeskaki, N., Eds.; Palgrave Macmillan: London, UK, 2020; pp. 49-96.

41. Koop, S.H.A.; Koetsier, L.; Doornhof, A.; Reinstra, O.; Van Leeuwen, C.J.; Brouwer, S.; Dieperink, C.; Driessen, P.P.J. Assessing the Governance Capacity of Cities to Address Challenges of Water, Waste, and Climate Change. Water Resour. Manag. 2017, 31, 3427-3443. [CrossRef] 
42. Termeer, C.J.; Dewulf, A.; Biesbroek, G.R. Transformational change: Governance interventions for climate change adaptation from a continuous change perspective. J. Environ. Plan. Manag. 2017, 60, 558-576. [CrossRef]

43. Hölscher, K.; Frantzeskaki, N. (Eds.) Transformative Climate Governance: A Capacities Perspective to Systematise, Evaluate and Guide Climate Action; Palgrave Macmillan: London, UK, 2020.

44. Tschakert, P.; Dietrich, K.A. Anticipatory Learning for Climate Change Adaptation and Resilience. Ecol. Soc. 2010, 15. [CrossRef]

45. Cairney, P. The Politics of Evidence-Based Policy Making; Palgrave Macmillan: London, UK, 2016.

46. Bosomworth, K. A discursive-institutional perspective on transformative governance: A case from a fire management policy sector. Environ. Policy Gov. 2018, 28, 415-425. [CrossRef]

47. Birchall, S.J.; Bonnett, N. Climate change adaptation policy and practice: The role of agents, institutions and systems. Cities 2021, 108, 103001. [CrossRef]

48. Peters, B.G. Advanced Introduction into Public Policy; Edward Elgar: Cheltenham, UK, 2021.

49. Granberg, M.; Glover, L. The Climate Just City. Sustainability 2021, 13, 1201. [CrossRef]

50. Olsson, D. Conditions of 'Sustainability': The Case of Climate Change Adaptation in Sweden; Karlstad University Studies: Karlstad, Sweden, 2018.

51. Baker, I.; Peterson, A.; Brown, G.; McAlpine, C. Local government response to the impacts of climate change: An evaluation of local climate adaptation plans. Landsc. Urban Plan. 2012, 107, 127-136. [CrossRef]

52. Uittenbroek, C.J. From Policy Document to Implementation: Organizational Routines as Possible Barriers to Mainstreaming Climate Adaptation. J. Environ. Policy Plan. 2015, 18, 161-176. [CrossRef]

53. Argyris, C.; Schön, D.A. Organizational Learning: A Theory of Action Perspective; Addison Wesley: Reading, UK, 1978.

54. Tosey, P.; Visser, M.; Saunders, M.N. The origins and conceptualizations of 'triple-loop' learning: A critical review. Manag. Learn. 2011, 43, 291-307. [CrossRef]

55. Argyris, C. On Organizational Learning; Blackwell: Oxford, UK, 1999.

56. SOU 2007:60. In Sverige Inför Klimatförändringarna-Hot och Möjligheter; The Swedish Government: Stockholm, Sweden, 2007.

57. Proposition 2017/18:163. In Nationell Strategi för Klimatanpassning; The Swedish Government: Stockholm, Sweden, 2018.

58. SMHI. Lathund för klimatanpassning; SMHI: Norrköping, Sweden, 2018.

59. Respondent Organisation 2. Regional Action Plan for Climate Adaptation; (public document); 2017.

60. Respondent Municipality 1. (interview). 2018.

61. Respondent Municipality 7. (interview). 2018.

62. Respondent Municipality 6. (interview). 2018.

63. Municipality 13. Climate Adapation Plan, (public document). 2015.

64. Respondent Municipality 2. (interview). 2018.

65. Respondent Municipality 10. (interview). 2018.

66. Respondent Municipality 9. (interview). 2018.

67. Respondent Municipality 3. (interview). 2018.

68. Municipality 1. Comprehensive Plan, (public document). 2018.

69. Municipality 12. Climate Adaptation Measures Plan, (public document). 2017.

70. Municipality 11. Comprehensive Plan, (public document). 2014.

71. Municipality 5. Comprehensive Plan, (public document). 2018.

72. Respondent Municipality 8. (interview). 2018.

73. Respondent Municipality 4. (interview). 2018.

74. Respondent Municipality 13. (interview). 2018. 